\title{
Study on the Phenomenon of Bank Liquidity Tail
}

\author{
Hongjian $\mathrm{Qu}^{1} \&$ Jianchun $\mathrm{Zhou}^{2}$ \\ ${ }^{1}$ Department of Marketing, Shanghai University of Engineering Science, Shanghai, China \\ ${ }^{2}$ Wujiang Shengwei Bauhinia Textile Co., Ltd, Suzhou, China \\ Correspondence: Hongjian Qu, Department of Marketing, Shanghai University of Engineering Science, Shanghai, \\ China.
}

Received: April 6, 2017

Accepted: May 17, 2017

Online Published: May 29, 2017

doi:10.5430/jbar.v6n2p1

URL: https://doi.org/10.5430/jbar.v6n2p1

\begin{abstract}
The entry of foreign banks, the spread of financial crisis, the marketization of interest rates and the impact of the point of time assessment lead to the phenomenon of bank liquidity tail, which has a negative impact on commercial banks, the financial system and the national economy. This paper is based on the current situation of the phenomenon of bank liquidity tail, analyzes the reasons of bank liquidity tail from two aspects of management and supervision system of bank liquidity, and proceed from the inner bank, the central bank's monetary policy, the external environment and so on, to find credit mismatches, credit term structure mismatch, the end of the month to pay the deposit reserve, the central bank focused on open market operations, the external macro environment are the main factors of bank liquidity tail. Therefore, this paper puts forward some countermeasures to solve the problem of bank liquidity from the perspective of liquidity supervision system, the bank's own management mode, the central bank credit rationing and the external environment change.
\end{abstract}

Keywords: Bank liquidity, Tail phenomenon, Reason, Influence, Countermeasure

\section{Introduction}

Since the promulgation and implementation of "regulations on the administration of foreign funded banks the management of foreign banks", foreign banks came to China and fiercely competed with the domestic banks, they attracted high-quality depositors through the "cherry picking effect", which seriously affected the liquidity of Chinese banking system. Subprime mortgage crisis gradually leaded to global financial crisis since 2007, thousands of banks such as Lehman brothers and other well-known banks had liquidity crisis. With the deepening and spreading of the crisis, the liquidity of Chinese commercial banks had been greatly affected. Since May 2013, the financial market interest rates soared across the board, overnight lending rate rose to $7.66 \%$ in June 20th, which was 2.24 times of overnight lending rate in May 7th, the liquidity crisis had a comprehensive upgrade. China liberalized interest rate control in July 20,2013, the risk of interest rate volatility caused by the interest rate liberalization and the conduction of the international financial crisis and other issues, which made the liquidity of Chinese banking system faced great impact. By the impact of the traditional assessment system, the banks are facing monthly, quarterly, and the timing of the regulatory assessment, these points will appear short-term liquidity impact assessment. In addition, the concentration of Treasury Deposits, paying for the statutory reserves, financial products and other factors, will lead to short-term liquidity shocks. These factors together at the same time, will lead to liquidity shocks in the month, quarter, the end of the formation. This month, quarter, the end of the entire banking system liquidity tensions, known as the phenomenon of bank liquidity Tail. The phenomenon of bank liquidity is very rare in the world, and becoming a unique landscape of Chinese finance. The phenomenon of bank liquidity, on the one hand, impacts bank loans stationarity, the commercial banks to adopt various means to increase the high interest savings, which add bank operating costs and liquidity management costs, is not conducive to the bank development; on the other hand, it affects the level of currency supply, weakens the effectiveness of macroeconomic policies, is not conducive to the country the macroeconomic regulation and control.

The phenomenon of Bank Liquidity Tail has a negative impact on commercial banks, the financial system and even the national economy, which has reached a consensus in the practical. From the domestic and international researches, the causes of liquidity risk mainly include two aspects: internal factors and external factors. Internal factors mainly include capital structure, corporate governance structure, salary system, external factors include macroeconomic 
policy, foreign exchange reserve size, central bank monetary policy, lender psychological changes (Zeng Gang, Li Guangzi, 2013; Deng Chao, 2015; Wang Yuming, Qu HongJian, 2014; Sun Guofeng, Cai Chunchun, 2014; Li Minghui et al., 2014; Wang Guozhi, Liu Yanmei, 2014; Shi Yonghui, 2014; Li Zeguang, Changrong 2015). In order to reduce the risks of bank liquidity, Guo Jinghua (2000), Tong Lun, Ding Zhan (2000), Shen PeiLong, Yan Zhaoxuan (2011), Gao Peng, You hua (2012), Lou Wenlong (2015) from the bank and the central bank monetary policy put forward a series of liquidity management strategy. The above researches are mainly for the analysis of the banking system liquidity, However, the theoretical researches on the phenomenon of bank liquidity are relatively scarce, only a small number of scholars have studied the phenomenon of the point of time assessment (Wu Huizhong, Hou Shiyu, 2011; Xu Hongshui, 2012; Wang Guanglong, Teng Fei, 2015), few scholars have analyzed the causes and influencing factors of the phenomenon of bank liquidity, or put forward the corresponding solutions to the phenomenon of bank liquidity. Different from the previous research, this paper mainly studies the phenomenon of single bank liquidity Tail, analyzes the causes of Bank Liquidity Tail and the influencing factors, which is to provide some policy references for the governance of Bank Liquidity Tail. The structure of this study are as follows: second part is the analysis of the current situation of the bank's popularity Liquidity Tail; the third part is about the causes of bank liquidity tail; the fourth part analysis of the influence factors of bank liquidity tail phenomenon; the fifth part is the countermeasures and suggestions to solve the phenomenon of bank liquidity.

\section{Analysis of the Current Situation of Bank Liquidity}

The phenomenon of bank liquidity tail is widespread, but few scholars have measured the phenomenon, so that the consideration of the amount of this phenomenon cannot be realized. Bank liquidity consists of two levels: monomer bank liquidity and liquidity of the banking system. This study focuses on the macro level of liquidity in the banking system, the liquidity is generally expressed in the interbank lending rate, the best measures of interbank rates are Shibor and Chibor. Bank liquidity tail mainly refers to the tense situation of the bank liquidity system at the end of the month, quarter or the year. If the liquidity of the banking system is tight, the direct performance is the increase of the interbank rate, in order to show the bank liquidity tail phenomenon, the index should be able to explain the monthly, quarterly and year-end interbank rates higher than other interbank rates. Therefore, this study uses the ratio of mean value of Shibor and Chibor of the 5 days at the end of the month and the other day of the month to indicate the phenomenon of bank liquidity. If the ratio is greater than 1 , it indicates the existence of bank liquidity tail phenomenon, and the greater the value, the more obvious the phenomenon of tail. This study uses the monthly data from October 2006 to April 2016 to analyze the phenomenon of bank liquidity tail.

Table 1. Description of bank liquidity Tail

\begin{tabular}{lll}
\hline & Shibor & Chibor \\
\hline Mean & 1.1109 & 1.1099 \\
Standard deviation & 0.2845 & 0.2821 \\
Variance & 0.081 & 0.080 \\
Minimum & 0.53 & 0.54 \\
Maximum & 2.71 & 2.70 \\
\hline
\end{tabular}

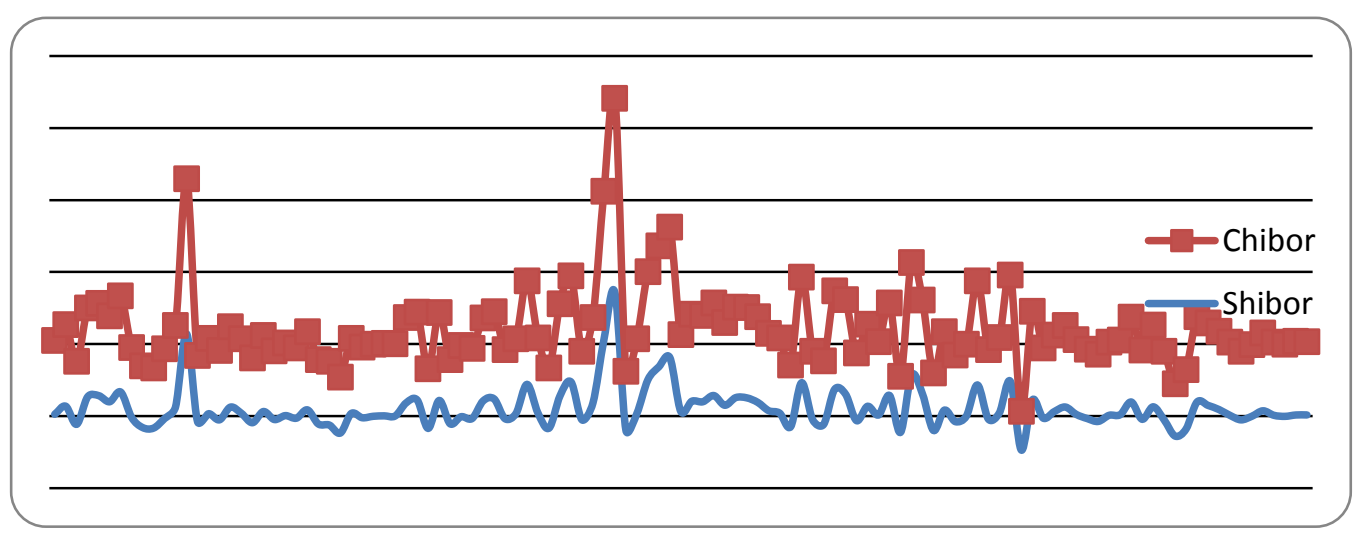

Figure 1. Line chart of bank liquidity trail 
The mean values of Shibor tail data and Chibor tail data are 1.1109 and 1.1099 respectively. They show that the phenomenon of bank liquidity is obvious, at the end of the month, quarter and year, the degree of liquidity stress is higher than that of other time (i.e., Tab. 1). The bank liquidity is more than 1 in most of the time, which verifies the existence of the bank liquidity. From the whole process of development, there are two peaks in October 2007 and in November 2010, which are both over 2, indicating that the bank liquidity is very tight and tail phenomenon is prominent during the period. From the whole development trend, between 2006 and 2012, the volatility of bank liquidity tail is larger; after 2012, the trend tends to be stable, which shows that the phenomenon of bank liquidity tail is relatively stable; especially after 2014, with the promulgation and implementation of "Notice on strengthening the management of commercial bank deposits deviation", the phenomenon of bank liquidity has been alleviated a lot, which shows that the effect of this institution is significant(i.e., Fig. 1).

\section{Causes of the Bank Liquidity Tail}

The bank liquidity tail consumes a large amount of manpower and material resources, which increases the cost of bank storage, and results in the mess of bank liquidity. The bank's investment and income are significantly unequivalence, and by the end of the month, quarter and year, commercial banks will find ways to absorb deposits, why is there such a contradiction? The root is the liquidity supervision system and bank operation mode. The following study will discuss the causes of bank liquidity tail from two aspects.

\subsection{The Perspective of Liquidity Supervision System}

Before the promulgation of "People's Republic of China commercial bank law amendment (Draft)" in June 2015, the provisions of the loan balance and the balance of deposits should not exceed $75 \%$ of the bank, which is an important indicator of state regulation. In order to achieve the deposit ratio of less than $75 \%$ of the regulatory red line, there are mainly two ways: one is to reduce lending, and the other is to increase deposits. The loan is an important source of income for commercial banks, which is also the lifeblood of the bank, it is impractical to reduce the loan from the perspective of income. In order to comply with regulatory red line, banks are willing and able to increase deposits, therefore, it is common practice for banks to encourage savings. The deposit loan ratio is calculated by the amount of the deposit and loan, and the scale of the deposit and loan is an important basis for the bank's influence and development speed. Among those factors, the deposit scale is the most basic and the important index, which determines the size of the loan. In addition, for depositors and external investors, due to the inability to accurately understanding of the quality of the bank's operations, they also consider the size of the bank as a major indicator of lending and investment. Accordingly, the size of the deposit has become the most important indicators of commercial banks. At the end of every month, quarter, year, absorb deposits rush point has become an important task of commercial banks, this approach is bound to cluster bank liquidity at that time. If each bank has this kind of phenomenon, the liquidity of the entire banking system inevitably become tense, bank liquidity carryover phenomenon occurs, which led to the bank liquidity tail.

\subsection{The Bank's Own Management Mode}

The operation of commercial banks is different from general industrial and commercial enterprises, their capital are few, debt is the main source of their funds. The main business of the bank is achieved through the "borrow short put long", this kind of mode of operation can easily lead to the mismatch of two typical credit resources. These two mismatches will lead to the habit of increasing demand for funds in the end of month, quarter, year. One of the mismatch is the loan direction mismatch. Commercial banks should have been able to allocate credit funds to less risky industries, such as strategic emerging industries, for the transformation and upgrading of the national economy. However, banks has allocated funds to local government financing platform loans, manufacturing and other industries to excess capacity, these industries do not have enough profits to repay the loan, and they often use "borrowing new loans to repay the old loans" to extend the bank non-performing loans. Loans are generally signed as an annual unit, loan repayment are often concentrated at the end of the month, quarter, year, the bank liquidity tail phenomenon prominent because that the loan can not be recovered on time, the point of liquidity tensions intensified. The second mismatch is the term structure mismatch. In the process of asset liability management, some commercial banks reduce deposit sources of funds, while bank loan funds did not decrease, on the contrary, it has the trend of expand, deposit demand and the trend of long-term loans are increasingly obvious, the term structure of deposits and loans are clearly mismatched. In order to make up for the shortage of short-term funds, banks often make capital supplement through financial services, trust business, etc. Due date of financial products and trust products often intersect with the supervision department assessment day monthly, quarterly, annual. Therefore, by the end of the month, quarter and year, the sensitivity of bank liquidity will increase, and liquidity tensions will lead to the phenomenon of bank liquidity tail. 


\section{Analysis of the Factors Influencing the Liquidity of Banks}

There are many factors that affect the liquidity of banks. We will mainly analyze them from three aspects as the following: the mismatch of internal credit resources, the central bank's monetary policy tools, and the impact of the external environment.

\subsection{The Impact of Mismatch of Bank Internal Credit Resources on Bank Liquidity}

Above analysis shows that the mismatch of bank's internal credit resources mainly refers to two aspects: the mismatch of the direction of the loan and the mismatch of the term structure. Obviously, there are some differences in the effect of mismatch between the direction of the loan and the term structure mismatch on bank liquidity.

From the mismatch of the credit direction, if the banks put resources from strategic emerging industries to overcapacity industry, the most direct manifestation is the increasing of excess capacity industry loans. And the increasing of non-performing loan ratio of the industry results in the increasing in the bank's non-performing loan ratio, the decline in bank loan recovery, the reduction in the number of bank funds, and the significant effect of bank liquidity tail. Therefore, the overall non-performing loan ratio of the banking sector is the main consideration of the direction of the mismatch of bank credit, the greater the NPL ratio, the more obvious the effect of bank liquidity.

From the mismatch of the term structure, if the bank loan funds are significantly higher than bank deposits, the term structure mismatch exists. The complexity of the calculation of the term structure of bank deposits and loans, and data acquisition is difficult, so we can increase the number of financial products and other financial management business to increase the number of auxiliary term structure mismatch .The greater the number of financial products and other information management business, the more obvious the maturity of the bank term structure, leading to the bank of the month, quarter, year-end liquidity impact is greater, and the phenomenon of bank liquidity tail is more obvious.

\subsection{The Impact of the Central Bank's Three Monetary Policy Tools on the Bank Liquidity}

The three tools of the central bank's monetary policy include the statutory deposit reserve ratio, rediscount rate and open market operations. There are significant differences that the three tools impact the phenomenon of bank liquidity.

The statutory deposit reserve ratio stipulates that commercial banks must pay a certain percentage of the deposit reserve, the greater the proportion, the more funds turned over, the less available funds, and the worse the liquidity of the banking system. The statutory reserve ratio is the main monetary policy tool of the Central Bank of China, and it is an important means for the central bank to control the liquidity of the banking system. Since 2007, the legal deposit reserve ratio has been adjusted to a higher frequency. As an effective means of monetary policy, the adjustment of the statutory reserve ratio has become the most effective way to adjust the liquidity of the banking system. Because Chinese commercial bank liquidity is paid on a monthly basis (at the end of each month to pay), the higher the deposit reserve ratio, the more the amount of reserves to be paid at the end of the bank, the less the bank funds, the more serious the liquidity of banks, the more obvious the phenomenon of bank liquidity.

The rediscount rate is the rate at which the bank will discount the enterprise to the central bank for rediscount. The higher the rediscount rate, the higher the cost of obtaining funds from the central bank. However, the initiative of the rediscount rate is in the hands of the commercial banks rather than the central bank, the bank rediscount business is not concentrated in the month, quarter, the end of the year, the liquidity of commercial banks is less affected by the tail effect.

Open market operation refers to foreign exchange operations and securities operations .The foreign exchange operations refers to adjust the quantity of foreign exchange, and securities repurchase transactions, including spot transactions, central bank bills and Short-term Liquidity Operation. The number of foreign exchange refers to the amount of the base currency used by the central bank for foreign exchange, the number of foreign exchange is reducing, it means that the amount of base money and bank funds is reducing, and bank liquidity will be tight. As the foreign exchange is not accounted for the end of the month, the project has little impact on the daily liquidity of banks, and will not lead to significant liquidity tail phenomenon, therefore, this research has ignored the impact of foreign exchange bank liquidity carryover phenomenon. Repurchase transactions are divided into positive repurchase and reverse repurchase, positive repurchase steam again funds, while the reverse repurchase throw in funds. In recent years, the central bank has been the use of reverse repurchase means of liquidity ,if the number of reverse repurchase are reducing at the month, quarter, the end, Bank liquidity will be tight and the phenomenon of bank liquidity will be significant. Spot trading is the central bank bond trading to delivery and return of funds at parallel market. If the bond is sold at the month, quarter, the end, Bank liquidity will be tight and the phenomenon of bank liquidity will be 
significant. Central bank bills are short-term debt issued by the central bank to commercial banks, If the number of central bank bills issued at the end of the month, quarter and the year is less than that of other periods, the liquidity of banks will increase comply with other periods, and the liquidity of banks will be significantly improved. Short term liquidity adjustment tool is a necessary complement to the regular operation of the open market, when the liquidity of the banking system temporary fluctuations, if the number of short-term liquidity adjustment tools issued at the end of the month, quarter and the year is less than that of other periods, the liquidity of banks will increase with respect to other periods, and the liquidity of banks will be significantly improved.

\subsection{The Impact of External Environment on Bank Liquidity}

The external environment includes the development of the national economy, the consumption of the residents, the stock market and the bond market. It is relatively large that the national economic development impact on bank liquidity, but there was no significant difference in liquidity between the month, the quarter and the end of the year. Therefore, the development of national economy has little effect on the bank liquidity. The overall consumption of residents is relatively average, while there will be a lot of shopping phenomenon at the end of the year, so it is obvious that the end phenomenon impacts on the liquidity. Stock market, bond market and Commercial Bank belong to the category of financial system. The stock market and the bond market are the direct financing channels, while the commercial banks are indirect financing channels, the three complement each other and replace each other. It will attract money from commercial banks to the stock market and bond market, reduce bank funds, if the stock market and bond market are prosperous at the end of month, quarter ,and it is significant that the phenomenon of bank liquidity at the end of the month, quarter and year-end .

\section{Countermeasures to Alleviat the Phenomenon of Liquidity Tail}

Above analysis shows that many factors will have an impact on the phenomenon of liquidity tail. So we should put forward some countermeasures to solve the problem of bank liquidity from the perspective of liquidity supervision system, the bank's own management mode, the central bank credit rationing and the external environment change.

\subsection{Continue to Perfect the Liquidity Supervision System}

In accordance with "regulations on the administration of foreign funded banks the management of foreign banks(Trial)", abolish the regulatory requirements for deposit and loan ratio, and regulate the bank liquidity coverage and liquidity rate. The CBRC should supervise the liquidity risk through aspects such as off-site inspection, on-site inspection and conversations with bank executives, from the aspects of bank credit direction and time mismatch, diversification of funds sources and stability, and market liquidity. In particular, it is necessary to strengthen daytime liquidity risk regulation to ensure that banks have sufficient daytime liquidity to meet the liquidity needs of different stress scenarios.

In accordance with the requirements of "the Notice on Strengthening the Management of Deposit Deviation of Commercial Banks", set up the deposit deviation degree and restrict the "red time" of the deposit to prevent and control the liquidity of the bank effectively. Adjust the existing deposit deviations, the adjusted end-of-month deposit deviation $=($ the average of last five days' deposit of the month - monthly average day deposit $) / 100 \%$ of the monthly average day deposit, this adjustment can not only change the current situation of "red time", but also effectively restrain the bank's "red time" phenomenon, avoid bank liquidity fluctuation, and alleviate the liquidity problem of bank.

\subsection{Change the Bank's Management Mode}

Commercial banks should change the mode of management and solve the problem of internal credit resource mismatch effectively. First of all, commercial banks should control the direction of credit rationing, increase the number of loans in the direction of strategic emerging industries, reduce the loans of government financing platform and manufacturing industry, improve the bank non-performing loan recovery rate and reduce the bank non-performing loans through rational allocation of resources to ensure that bank credit funds to meet the bank liquidity needs. Second, the commercial banks should make reasonable planning of deposit and loan terms to reduce the bank deposit and loan period mismatch phenomenon, in particular, the banks should rationally manage the maturity date of financial and asset management and avoid the phenomenon of concentrated due at the end of the month, so to alleviate the phenomenon of bank liquidity effectively.

\subsection{Monetary Policy Dynamic Adjustment of the Central Bank}

The central bank should adjust the monetary policy according to the state of the liquidity of the banking system to meet the demand for bank liquidity. First of all, the central bank should adjust the statutory deposit reserve ratio 
dynamically, according to the market situation to increase or lower the proportion of payment, in particular, to change the current stage of the end of the deposit reserve deposit situation, according to commercial banks to pay the size of the deposit reserve business banks are divided into three parts, respectively, in the beginning of the month, the end of the month and the end of the month deposit reserve to pay, so as to avoid the liquidity of the entire banking system fluctuations, effectively alleviate the phenomenon of bank liquidity. Second, according to the demand situation of the bank's liquidity, the use of dynamic open market operation to adjust the liquidity of the banking system supply, when the end of the liquidity crisis, the use of repurchase transactions, central bank bills and short-term liquidity adjustment tools and other means to stabilize the flow Sexual fluctuations, so as to ease the phenomenon of bank liquidity.

\subsection{Suppresses External Environmental Fluctuations}

From the impact of the external environment, the economic cycle fluctuations, consumer concentration, the stock market and bond market volatility will affect the bank liquidity trailing phenomenon. These changes in the external environment are usually more difficult, which need a lot of policy tools to achieve a certain effect. At the national level, measures such as consumer guidance, fiscal policy support and monetary policy adjustment can be used to avoid fluctuations in the business cycle, consumer concentration, stock market and bond market volatility, thereby reducing the impact of these external environments on bank liquidity and ease the phenomenon of bank liquidity.

\section{References}

Deng Chao, Zhou Feng, TANG Ying. (2015). Study on the impact of excessive loans on the liquidity creation of Chinese commercial banks. Journal of Financial Economics, (6), 39-48. (In Chinese). http://kns.cnki.net/KCMS/detail/detail.aspx?dbcode=CJFQ\&dbname=CJFDLAST2016\&filename=JIRO201506 004\&v=MzA1ODYyZl11ZG5GaUhoV3IvQUx5VFpZYkc0SDIUTXFZOUZZSVI4ZVgxTHV4WVM3RGgxV DNXVHJXTTFGckNVUkw=

Gao Peng, You Hua. (2102). Liquidity risk management of commercial banks. China Finance, (20), 56-57. (In Chinese). http://kns.cnki.net/KCMS/detail/detail.aspx?dbcode=CJFQ\&dbname=CJFD2012\&filename=ZGJR201220024\& $\mathrm{v}=$ MDU5ODRSTDJmWXVkbkZpSGhXN3pLUHlyQmZMRzRIOVBPcjQ5SFIJUjhlWDFMdXhZUzdEaDFU M3FUcldNMUZyQ1U=

Guo Jinghua. (2000). Discussion on the risks and management of the liquidity of commercial banks in China. Journal of Central University of Finance and Economics, (6), 30-35. (In Chinese). http://kns.cnki.net/KCMS/detail/detail.aspx?dbcode=CJFQ\&dbname=CJFD2000\&filename=ZYCY200006006 \&v=MTQxNTBkbkZpRGtVcnpCUHpUSWQ3RzRIdEhNcVk5RllvUjhlWDFMdXhZUzdEaDFUM3FUcldNM UZyQ1VSTDJmWXU=

Li Minghui, Sun Sha, Liu Liya. (2014). The impact of monetarypolicy on the liquidity creation of commercial banks - Empirical evidence from Chinese banking industry. Finance and Economics, (10), 50-60. (In Chinese). http://kns.cnki.net/KCMS/detail/detail.aspx?dbcode=CJFQ\&dbname=CJFDLAST2015\&filename=CMJJ20141 0006\&v=MDQ1Mjg3RGgxVDNxVHJXTTFGckNVUkwyZll1ZG5GaURrVTd6SUppREJaTEc0SDIYTnI0OU ZZb1I4ZVgxTHV4WVM=

Li Zeguang, Chang Rong. (2015). The financial system will significantly affect the bank liquidity creation?-Based on the study of cross-border bank data. Comparison of Economic and Social Systems, (6), 77-87. (In Chinese). http://kns.cnki.net/KCMS/detail/detail.aspx?dbcode=CJFQ\&dbname=CJFDLAST2016\&filename=JJSH201506 009\&v=MDI1NjJDVVJMMmZZdWRuRmlEa1ViL05MeWZZWnJHNEg5VE1xWTIGYllSOGVYMUx1eFIT NORoMVQzcVRyV00xRnI=

Lou Wenlong. (2015). Liquidity Management of Commercial Banks in the Process of Interest Rate Marketization. Finance Forum, (9), $\quad 3-8 . \quad$ (In http://kns.cnki.net/KCMS/detail/detail.aspx?dbcode=CJFQ\&dbname=CJFDLAST2015\&filename=CSJR20150 9003\&v=MjM5MjJDVVJMMmZZdWRuRmlEa1VidktKajdCZkxHNEg5VE1wbzlGWjRSOGVYMUx1eFITN ORoMVQzcVRyV00xRnI=

Shen Peilong, Yan Zhaoxuan. (2011). Improved methods and empirical analysis of liquidity gap management in commercial banks. Finance Tribune, (3), 10-15. (In Chinese). http://kns.cnki.net/KCMS/detail/detail.aspx $?$ dbcode $=$ CJFQ \&dbname $=$ CJFD2011\&filename $=$ CSJR201103005\& v=MTE3NDhZdWRuRmlEa1ZyelBKajdCZkxHNEg5RE1ySTIGWVISOGVYMUx1eFITNORoMVQzcVRyV0 0xRnJDVVJMMmY= 
Song Huizhong, Hou Shiyu. (2011). Effective suppression of "red time point" logical starting point. China money, (4), 30-33.

(In

Chinese).

http://kns.cnki.net/KCMS/detail/detail.aspx $?$ dbcode $=$ CJFQ\&dbname $=$ CJFD2011\&filename $=$ ZGHC201104011 $\& v=M T g z O D N M d X h Z U z d E a D F U M 3 F U c l d N M U Z y Q 1$ VSTDJmWXVkbkZpRGtWNy9BUHlyRGJiRzRIOU RNcTQ5RVpZUjhlWDE=

Tong Pin, Ding Zhisuo. (2000). Characteristics and institutional background of liquidity management in Chinese commercial banks. Economic Research, (9), 57-61. (In Chinese). http://kns.cnki.net/KCMS/detail/detail.aspx?dbcode $=$ CJFQ \&dbname $=$ CJFD2000\&filename $=J J Y J 200009007 \& \mathrm{~V}$ $=$ Mjc4NzkxRnJDVVJMMmZZdWRuRmlEa1Y3dkxMeWZTWkxHNEh0SE1wbzlGWTRSOGVYMUx1eFIT NORoMVQzcVRyV00=

Wang Guanglong, Teng Fei. (2015). Deposit "red point" and "prisoner's dilemma". Wuhan Finance, (1), 37-40. (In Chinese).

http://kns.cnki.net/KCMS/detail/detail.aspx?dbcode=CJFQ\&dbname=CJFDLAST2015\&filename=YHQY2015 01011\&v=MTEzMTMzcVRyV00xRnJDVVJMMmZZdWRuRmlEa1ZMM0pQQ1hhZDdHNEg5VE1ybzlFWll SOGVYMUX1eFITNORoMVQ=

Wang Guozhi, Liu Yanmei. (2014). An empirical study on the influencing factors of liquidity risk of Chinese listed commercial banks. Journal of Yanshan University (Philosophy and Social Sciences Edition), (3), 119-124. (In Chinese).

http://kns.cnki.net/KCMS/detail/detail.aspx?dbcode=CJFQ\&dbname=CJFD2014\&filename=YSDS201403026 \&v=MDYxOTNJOUhZb1I4ZVgxTHV4WVM3RGgxVDNxVHJXTTFGckNVUkwyZl11ZG5GaURrVmIzSVB EN1BmYkc0SDIYTXI=

Wang Yuming, Qu Hong-jian. (2014). Effects and empirical tests on the liquidity of commercial banks. Journal of Learning and Research, (12), 127-130. (In Chinese). http://kns.cnki.net/KCMS/detail/detail.aspx?dbcode=CJFQ\&dbname=CJFDLAST2015\&filename=XXTS20141 2025\&v=MDgwNzExVDNxVHJXTTFGckNVUkwyZl11ZG5GaURrV3IvS1BUWGZmYkc0SDIYTnJZOUhZ WVI4ZVgxTHV4WVM3RGg=

Xu Hongshui. (2012). The end of the deposit and loan "red point": causes, ways and countermeasures. China money, (12), 31-35. (In Chinese). http://www.cqvip.com/QK/85239X/201212/44382348.html

Zeng Gang, Li Guangzi. (2013). Study on influencing factors of commercial bank liquidity. Journal of Financial Supervision, $\quad(10), \quad 40-55.4$ (In $\quad$ Chinese). http://kns.cnki.net/KCMS/detail/detail.aspx?dbcode=CJFQ\&dbname=CJFD2013\&filename=JRJG201310003\& $\mathrm{v}=$ MTQ0Nzc0UjhlWDFMdXhZUzdEaDFUM3FUcldNMUZyQ1VSTDJmWXVkbkZpRGxVcnpMTHovQmFi RzRIOUxOcjQ5Rlo= 